Studia Anglica Posnaniensia 52(4), 2017

doi: 10.1515/stap-2017-0018

\title{
MISFITS OF WAR: FIRST WORLD WAR NURSES IN THE DAUGHTERS OF MARS BY THOMAS KENEALLY
}

\author{
ANNA BRANACH-KALLAS** \\ Nicolaus Copernicus University in Toruń
}

\begin{abstract}
The article is an analysis of the representation of Australian nurses in Thomas Keneally 2012 First World War novel, The Daughters of Mars. Inspired by rigorous research, Keneally fictionalizes the lives of two nursing sisters in the Middle East, on a hospital ship in the Dardanelles, as well as in hospitals and casualty clearing stations on the Western Front. His novel thus reclaims an important facet of the medical history of the First World War. The author of the article situates her analysis in the context of historical research on the First World War and the Australian Anzac myth, illuminating the specifically Australian elements in Keneally's portrait of the Durance sisters. She demonstrates that The Daughters of Mars celebrates the achievements of "Anzac girls", negotiating a place for them in the culture of commemoration. Yet, at the same time, Keneally attempts to include his female protagonists in the "manly" world of Anzac values, privileging heroism over victimization. Consequently, they become "misfits of war", eagerly accepting imperial and nationalist ideologies. Thus, in a way characteristic of Australian First World War literature, The Daughters of Mars fuses the tropes of affirmation and desolation.
\end{abstract}

Keywords: nurses; Anzac; Gallipoli; trauma; endurance; hospital ship; gender; commemoration.

In The Daughters of Mars, published in 2012, winner of the 2013 Colin Roderick Award for the best representation of "Australian life in any of its forms" (Pierce 2015: 47), Thomas Keneally explores the war experience of two Australian sisters from New South Wales, Naomi and Sally Durance, who volunteer in 1915 as military nurses. ${ }^{1}$ The author himself confesses in an interview,

* Department of English, Nicolaus Copernicus University, ul. Bojarskiego 1, 87-100 Toruń,email: kallas@umk.pl

* This research was supported by grant DEC-2013/11/B/HS2/02871 from the Polish National Science Centre (Narodowe Centrum Nauki).

1 Thomas Keneally, winner of the Booker Prize for Schindler's Ark, explored the legacy 
I was fascinated by the fact that women very young from shires and townships that had existed for maybe 80 or 100 years could deal with this tide of damage to young flesh, a quite unrelenting tide of, in many cases, previously unimagined damage, such as the terrible inroads gas made on the linings of lungs and throats. And, of course, shellshock. To be able to do this for days on end, particularly in clearing stations without cracking was something that fascinates me about women.

(Simon 2013)

Inspired by wartime diaries, the history of the Australian Medical Services in World War I (1930-1943) by Colonel Arthur G. Butler, Australia's official military medical historian, Janet Butler's recent studies of nursing at Gallipoli, and The Other Anzacs (2009) by popular historian Peter Rees in particular, Keneally uses historical documentation to fictionalize the lives of nurses during the First World War from nursing in the Middle East, on a hospital ship in the Dardanelles, on the Greek Island of Lemnos, to hospitals and casualty clearing stations on the Western Front. Until recently, the "medical war" has been placed outside the history of First World War combat. The experience of medical staff on hospital ships in particular has received very little attention (Acton 2015: 216-217).

A monumental, five-hundred-page-long novel, The Daughters of Mars thus reclaims a little known history, an important gesture of revision not only in relation to the Australian World War One tradition. Certain aspects of the novel might seem puzzling to a reader accustomed to Western European narratives of trauma and disenchantment, yet, as I hope to demonstrate, they gain meaning in the specifically Australian context.

If women were allowed into the public sphere in Britain and its dominions during the First World War, they were welcome to help, provided they did not challenge the conservative gender boundaries (Ouditt 1994: 87). As Susan R. Grayzel (1999: 11) reminds us, the term "home front" began to be used during the 1914-1918 conflict, as part of a war propaganda that coded the military front as exclusively masculine and the home front as exclusively feminine. Women were supposed to be guardians of the home, who had to endure masculine duties only "for the duration" (Grayzel 1999: 119; Higonnet et al. 1987: 7). In reality, the First World War involved civilians on an unprecedented scale; the boundaries between the two fronts were porous, yet, "the idea of separate fronts helped to maintain the status quo of gender identities and enabled the reinterpretation of popular assumptions about the appropriate roles of men and women during the war without threatening the

of the First World War in an earlier novel, Gossip from the Forest (1975). Keneally's focus on the past seems motivated by a pressing need "to invest a chaotic present with some order and invoke a communal memory" (Bird 2000: 193). 
social order" (Grayzel 1999: 11). In this sense, the nurses' location, as women performing traditional caring roles in the war zones, was ambiguous and unsettling (Christie 2014: 225). They were therefore constructed in the official discourse as willing to sacrifice themselves not only for King and Country but for their men, creating a "a sphere of maternal care within the war arena" (Christie 2014: 231). As Christine E. Hallett (2014: 30) emphasizes, the stereotype of the serene, maternal nurses conceals the violence confronted by these "veiled warriors" in the theatre of war. If we define trauma as a wound of the mind caused by a close encounter with violence and death, which challenges ordinary human adaptation to life and exceeds simple understanding, nurses were on a daily basis exposed to such terrifying experiences during the First World War. While in the past their traumatic responses were regarded as secondary trauma, today scholars suggest that "constant witnessing and participating in severe injury and death are directly rather than vicariously traumatic" (Acton \& Potter 2015: 5). Through longterm exposure to war stressors nurses suffered from post-traumatic stress disorders such as hypervigilance, amnesia, flashbacks, numbing, ego fragmentation, and other shock reactions. ${ }^{3}$ Synchronously, however, they also developed coping strategies, which allowed them to experience a sense of satisfaction in their work (Acton \& Potter 2015: 46).

Over 3,000 Australian nurses enlisted in the Australian Army Nursing Service (AANS) or volunteered for other organizations, such as the Red Cross, the Queen Alexandra's Imperial Military Nursing Service or privately sponsored hospitals (Harris 2014: 113; Australian War Memorial, hereafter abbreviated AWM). Twenty-five died during their service (AWM). Initially, in contrast to Canadian nurses, Australian nurses had only "honorary" rank, which caused tensions concerning authority with the male medical staff. They became army officers in May 1916, when they began to wear badges of rank, equivalent to major, captain or lieutenant (Rees 2015: xiv). War nursing was very different from the organized routine of Australian hospitals. Nurses had to deal with a volume of work that challenged their standards of nursing duties: "in 1915, one military nurse with

2 In her study of allied nurses of the First World War, Hallett enumerates three myths that have transformed the First World War nursing sister into an icon: the myth of the mistreated VAD, of the romantic nurse in love with her patient, and the nurse-heroine ready to sacrifice herself to save the men in her care and to win the war. While the first two myths were cemented in the post-war years by such widely-read literary works as Vera Brittain's Testament of Youth (2014) and Ernest Hemingway's A Farewell to Arms (1929), in their diaries nurses constructed themselves as fearless participants in dangerous warfare (Hallett 2014: 2-14).

3 For a general introduction to the concept of trauma, see Herman Lewis 1992; Caruth 1995a. On women's trauma during the First World War, see Grayzel 1999; Ouditt 1994; on the trauma of the medical personnel, see Hallett 2014; Acton \& Potter 2015. 
some untrained orderlies took responsibility for a ward of 200 patients, and one Australian hospital, with only 53 trained nurses, looked after nearly 1000 patients" (Harris 2014: 113). However, they were paid less than male officers of the same rank and sometimes even less than male orderlies (Rees 2015: xiv-xv).

Although they wrote hundreds of diaries, the story of First World War nurses remains marginalized in Australia. ${ }^{4}$ Collective remembrance is still dominated by the first landing of the Australian and New Zealand Army Corps (Anzac) forces at Gallipoli on 25 April 1915, which has acquired a mythic status in Australian national memory. This baptism of fire transformed the fourteen-year old Australian federation into a true nation, "producing the emotional / sentimental foundations of nationhood" (Keshen 2003: 20). After Gallipoli, the term "Anzac" began to be used exclusively in reference to Australian troops and became legally protected in Australia from any derogatory statements (Keshen 2003: 8, 16). The Australian government, the veterans, the historians, the media, and the general public created a national narrative of Australianness, fusing the official Anzac tradition with the folkloric myth of the Australian digger or bushman (Reynaud 2014: 300; Seal 2004: 1). ${ }^{5}$ Significantly, the myth of the Anzac involved "the naturalisation of a masculine national identity" (Cooper 1993: 421), based on physical prowess, anti-authoritarianism, mateship, outstanding courage, sardonic humor, and the tendencies of swearing and drinking, attributes connected with Australia's pioneering past (Seal 2004: 3; Keshen 2003: 8). The Anzac persona excluded Indigenous Australians, migrants of a non-British origin, and women (Seal 2004: 18; Rees 2015: 308). According to Annabel Cooper,

While the war was claimed to have unified Australia and given it its first sense of nationhood, the limits of the arena within which the national character was identified and tested were clear. National character was not proven in the great variety of support work performed by women and men which was necessary to keep soldiers in the fighting line.

(Cooper 1993: 407)

$4 \quad$ Much research has been done on Australian nurses since the 1970s. See Harris (2014) for the archival material available about First World War nurses in Australia and the recent academic works devoted to their work. See also the Australian War Memorial for photographs of and interviews with Australian nurses. The Australian television drama series Anzac Girls, released in 2014, has also popularized knowledge about their work at Gallipoli and on the Western Front.

5 In Inventing Anzac: The Digger and National Mythology, Seal explains that the Anzac tradition "is a complex cultural process and institution involving the formal, official apparatus of Anzac Day, war memorials - particularly the Australian War Memorial in Canberra - the army, the Returned Soldiers' and Sailors' Imperial League of Australia (RSSILA) and similar organisations, and, ultimately, the politics of nationalist and military pragmatics" (2004: 4). According to the myth, the Australian bush conditions demanded particular strength, courage, and adaptability (Keshen 2003: 8). See Seal (2004) for a detailed discussion of the Australian national mythology. 
In spite of several efforts at inclusion, the masculine Anzac myth dominates the popular memory of the war in Australia today (Reynaud 2014: 300). As Frank Bongiorno contends, "the term 'Anzac' is more than 25 April; it refers to an entire culture of military commemoration and war remembrance that links Australian national identity to military endeavour" (2014: 81). ${ }^{6}$ If several academics contest the hegemonic Australian legend today, its popular image is resistant to change and reverence for the Anzac has not decreased as we commemorate the centenary of the First World War (Reynaud 2014: 301; Rhoden 2014: 277).

Australian Great War literature has contributed to the celebration of the Anzac manly values; "the Anzac themes" still persist in twenty-first century fiction. According to Clare Rhoden, in contrast to the British futility myth, the Australian Great War writing style "nagivate[s] the contested territory where the war figures, at one extreme, as a foundational event, and at the other, as a devastating national tragedy from which the country has yet to recover" (2014: 286). ${ }^{7}$ In The Daughters of Mars, Keneally also fuses the Australian tropes of affirmation and desolation (see Rhoden 2014: 276). The novel abounds in gruesome, tragic, and moving scenes, which depict the exhausting work of Australian nurses in the Dardanelles and on the Western Front, yet at the same time extoll their courage and loyalty. The focus of this third-person narrative is either on Naomi or Sally, and this double perspective allows Keneally to examine the nurses' war experience from different professional angles (e.g., the work of triage nurses/ anesthetic nurses/ matrons) and disparate personal responses to war. Consequently, while celebrating the achievements of "Anzac girls", Keneally negotiates a place for them in the culture of commemoration. However, at the same time, the Australian writer attempts to include his female protagonists in the "manly" world of Anzac values, privileging heroism over victimization (see Rhoden 2014: 276).

At the beginning of the novel, the relationship between the Durance sisters is tense, and is based on grudges and misunderstandings. Naomi has early moved away from home to work at the Royal Prince Alfred Hospital in Sydney, whereas Sally is a country nurse in the Macleay Valley in rural New South Wales, and lives with their ageing parents on a dairy farm. When their mother suffers the agony of post-metastasis cervical cancer, it is Sally who takes care of

6 As a number of Australian historians observe, since the 1990s the history of Australia has been the object of relentless militarisation: "the commemoration of war and understandings of our national history have been confused and conflated" (Lake et al. 2010: iii). By transforming 25 April into the Australian story, Australians have forgotten that Gallipoli was a tremendous defeat and have distorted its imperial context (Lake et al. 2010: iv). For a discussion of the evolution of the Anzac narrative, see Reynaud 2014; Spittel 2014; Bongiorno 2014; Gadzina 2015.

7 For a discussion of Australian Great War fictional style, see Rhoden 2014: 276-277. 
her and often considers the option of terminating her terrible pain. Naomi returns home on the night their mother dies and Sally suspects that her sister has used her stash of morphine to mercifully end her life. The murder of their mother becomes Sally's private obsession; only the war provides her with an unexpected avenue of escape. Naomi enlists immediately and expects her sister to continue to take care of their father; Sally is torn between a traditional conception of female duty and the prospect of adventure, liberation, and professional challenge. Yet, "something was rampant in Sally, something that said crazily that Naomi should not feel entitled to keep the whole of the war and leave Sally with the crumbs of a languishing peace" (Keneally 2013: 14). The country nurse and the city nurse are both accepted and depart together from Melbourne. Their relationship remains cold and aloof in Colombo, Port Suez, and Cairo. Only the confrontation with death at Gallipoli and the sinking of their ship in the Aegean Sea will open them up to each other.

Keneally's representation of the Gallipoli battles from the perspective of nurses on a hospital ship is a central element of the revision of Australian national mythology in The Daughters of Mars. As mentioned before, for Australians, the campaign is usually "associated with Australian soldiers charging bravely up the steep and barren slopes of Gallipoli". Australian nurses dressing hundreds of wounded soldiers on hospital ships, ferrying them between the Peninsula and the hospitals on the nearby Greek islands of Imbros and Lemnos, the remote Alexandria, Malta or England, have been marginalized in the collective memory (The Nurses' Experience 2015: 9). According to Janet Butler, "[t] the dominance of the Anzac mythology and the privileging of the voices of combatants have perpetuated this silence" (Butler 2003: 47). In reality, the enormous casualties were a challenge to the medical staff and, as there were no medical units on the ground at Gallipoli, "the hospital ships effectively became casualty clearing stations for first-line medical treatment" (Rees 2015: 37). For the nurses in The Daughters of Mars, Gallipoli is sheer chaos, an incessant source of bodies to wash, swab, cut, and dress: "It worked many shifts. Like a factory" (Keneally 2013: 68). The nurses' confrontation with hundreds of injured soldiers is a shock because of its scale - the volume of wounded and the enormity of their suffering. As Meryn Stuart suggests, for many nursing sisters during the First World War the "rapid, assembly-line admissions and evacuations" were most stressful and frustrating. The pace of work and the impersonal, hasty nature of the rites they were supposed to perform challenged professional and ethical procedures studied at nursing schools (Stuart 2008: 14; also see Harris 2014: 115). In The Daughters of Mars, the medical personnel struggle in vain to reduce the chaos to order, realizing the inadequacy of their efforts and clinical expertise in front of the "torrent of the harmed" (Keneally 2013: 75). 
Keneally subtly illustrates the traumatic impact of the 1915 Gallipoli campaign on the Durance sisters. As Santanu Das suggests, the right to trauma was denied to First World War nurses, whose suffering could never equal that of men: "If the nurse falls prey to trauma herself while sifting through her cargo of mutilated flesh, hers is a shame that dare not speak its name" (Das 2005: 195). The nurse's task was to contain her own emotions as well as those of her patients - while stoic resilience was applauded, breakdown was severely stigmatized (Acton \& Potter 2015: 46). Consequently, Keneally reclaims in his work a traumatic experience marginalized by accounts focused on men. To Sally, working below deck,

\begin{abstract}
the swabbing and dressing was more like a preoccupying mercy to herself rather than the soldier. By these exercises she kept saneness amidst the stench and the weighty tang of blood. The customary nature of these small ceremonies of nursing kept her eyes from taking in the broader scope of injury from bulkhead to bulkhead.
\end{abstract}

(Keneally 2013: 79)

Naomi in turn is selected as a triage nurse; the weight of responsibility proves too stressful for her as she realizes that the orderlies often confuse the tags, and she does not possess enough knowledge and strength to be "in authority over the shades of life and death that were so hard to tell from each other" (Keneally 2013: 84). Sally, who replaces her the next day, proves much more confident. However, once they retire to their cabins, both sisters realize that nurses, surgeons, and orderlies have saved many lives on that day but, because of the havoc, they have made several mistakes and have killed their men as well. For Naomi in particular, this realization proves an unbearable source of anguish; she experiences guilt, numbing, and emotional breakdown.

In The Daughters of Mars, the omnipresence of bodily parts, nauseous smells, and deafening noise affects the women as deeply as it does the men fighting at the front. Entrusted with the task of repairing human debris, the nurses transgress the abject boundary between self and other; having soaked their aprons, the men's blood covers the women's breasts and bellies - "the smell of blood had penetrated even as far as skin" (Keneally 2013: 81). In shocking scenes illustrating the nurses' corporeal absorption of war Keneally shows how "Young, healthy, well-educated women became the charwomen of the battlefield, the cleaners of the worst human waste we produce, the symbolic bearers of all its pollution and disease" (Marcus 1989: 126). Because of the nervous tension and condition of hypervigilance in which they perform their duties, both sisters suffer from amenorrhea. ${ }^{8}$ They thus experience trauma in the

8 On the phenomenon of amenorrhea during the First World War see Trevisan 2001: 119. 
most intimate sense within their bodies, "polluted carriers of a terrible knowledge" (Marcus 1989: 126). The traumatic experience imposes, however, a new perspective and reaffirms bonds that seemed inexistent before: after Gallipoli, Sally and Naomi "embraced with a fierceness impossible to imagine somewhere normal - in some place where shared crimes counted. It has taken horror, Sally thought, to make us sisters" (Keneally 2013: 81). Moreover, their common experience creates strong relationships with other nurses, similar to the phenomenon of bonding experienced by men during the First World War. ${ }^{9}$ As Butler contends, the war triggered a sense of community among Australian nurses, based on shared trauma and a sense of common achievement (2003: 57).

It is important to emphasize that Keneally's portrait of nurses in The Daughters of Mars questions the legacy of the radical erosion of female identity, popularized by such works as Mary Borden's The Forbidden Zone (1929) or Vera Brittain's Testament of Youth (1933). In their analyses of nurses' memoirs, several scholars suggest that during the First World War nursing sisters and VADs experienced a sense of marginalization. While the concept of service involved them directly in action as participants of the war effort, they felt that they could not really understand the horror of the battlefields and suffered from a profound sense of alienation or even emotional death (see Ouditt 1994: 45; Das 2005: 188). As Das contends,

For the First World War nurses, the fundamental unsharability of the ordeal, and
yet the juddering of the senses by knowing and serving the wounded body so
closely, leads to a crisis of experiencing .... If active service at the front was
considered the supreme form of sacrifice, nursing - deemed the 'second best' -
becomes a more insidious form: a constant emptying out of oneself before great
need and greater pain, and yet somehow always falling short.

(Das 2005: 192)

While Keneally's nurses are forced to become witnesses of men's obscene wounds and extreme physical pain, their dominant feeling is that of pride and sense of achievement. The female protagonists suffer from anguish and feelings of guilt at the massive death of soldiers, yet they do not feel alienated and excluded from the drama of war. Although the demands of nursing often result in feelings of anxiety and helplessness, in The Daughters of Mars "Touching the wounds of soldiers is the most intimate way of body-witnessing history, witnessing in and through exposed flesh; repairing the wounds marks the female body with the knowledge of actually shaping that history" (Das 2005: 227).

9 On male bonding and strategies of emotional survival based on mateship during the First World War, see Bourke 1996: 124-170; Roper 2009: 119-201. 
Furthermore, Naomi, Sally, and their friends are depicted by Keneally not only as witnesses, but also participants of war in their own rights. During the First World War, the hospital ship was the front environment in which nurses were exposed to the same risks as the male medical personnel and their patients (Acton 2015: 219). Working as a triage nurse on the deck of the Archimedes, Sally is directly exposed to life-threatening situations:

For the moment Sally was alone with colored cards in her hands and a sense of
rawest and clumsiest knowledge. As well as all else there were detonations from
ashore again, and shells aimed at ships around. This fire impressed a person more
here in the open and made sure that you understood you were part of their business.
(Keneally 2013: 82)

When the "ship of groans" (Keneally 2013: 91) delivers its cargo of 800 men to Egypt, Sally, who has become an anesthetist and witnesses amputations and deaths every day, realizes that the true meaning of their name is "En-durance" (Keneally 2013: 88). She thus questions the association of femininity with passivity and frailty. The Antipodean nurses in The Daughters of Mars are therefore war heroines, who acquire a profound, visceral knowledge about the war. By highlighting their professional skills and tenacity, Keneally endows them with a sense of agency. What is more, as illustrated in the chapters depicting the sinking of the Archimedes in particular, like soldiers, they are directly exposed to dismemberment and death.

Interestingly, Kenneally appropriates here the New Zealand history of the Marquette, substituting Australian nurses for New Zealand ones. On 23 October 1915, a German submarine torpedoed the British transport ship Marquette in the Aegean Sea. Apart from a cargo of troops, ammunition, mules, and horses, the ship was carrying the Number 1 New Zealand Stationary Hospital. The Marquette did not have a Red Cross painted on its sides, which made it an obvious target for the German U-boat. Twenty-two New Zealand men and ten female nurses lost their lives (Christie 2014: 225). According to Sarah Christie, in New Zealand collective memory, the sinking of the Marquette was constructed as a narrative of the nurses' sacrifice, a story of courageous young women who, in spite of injury and exhaustion, put the needs of others first. Yet, since their bravery transgressed gender norms, they were also referred to as "honorary men". While during the First World War male death was tragic but expected, female death undermined the idea that men waged war for the protection of women and children (Christie 2014: 228-233). ${ }^{10}$ As mentioned

10 As Christie demonstrates, in New Zealand the media constructed the Marquette nurses as tragic heroines of war, both womanly and manly in their bravery. This was possible "because it emphasized Britishness and was also framed as exemplifying feminine 
before, women's presence so close to the front radically challenged the traditional relationship between war and gender (Butler 2003: 51). Keneally's fictional vision follows closely the historical accounts. In The Daughters of Mars the Archimedes, travelling "blacked-out" back to the Dardanelles without the customary protection of hospital ship markings, transporting troops, horses and mules together with the medical staff, is torpedoed by a U-boat. In dramatic circumstances, men and nurses jump overboard; some drown, some are cut in half by the ship's propeller. Others die or are seriously injured when a lifeboat lowered from the sinking vessel crashes into another. Most survivors, including the Durance sisters, scramble on rafts and copper tanks, and hold on to them, drifting for hours. If Gallipoli proves more traumatic for Naomi, who momentarily loses her social grace, while the more timid and restrained Sally gains confidence in herself, the roles are reversed during the sinking of the Archimedes: Naomi, an excellent swimmer, saves other lives and takes command, "like a woman with a plan" (Keneally 2013: 133). Eventually, they are rescued by a British naval launch and a French destroyer which transport them to the island of Lemnos. However, six women die, several are seriously injured, and some, including Sally, suffer from post-traumatic stress disorder.

The sinking of the Archimedes and the subsequent incidents on the island of Lemnos in Keneally's novel throw into relief the anxiety about the transgression of gender norms during the First World War. In depicting his female protagonists as war heroines directly exposed to the threat of death, Keneally questions "the stereotypical presentation of women as war's 'other' on which so much of the 'home fires' mythology depended" (Ouditt 1994: 16). The heroism displayed by women during the tragedy convinces the Durance sisters that men are not stronger than women; the latter did not behave hysterically while the ship was sinking, while several men drifted away from their raft. Naomi's conclusion that "They'll never be able to print the story of the Archimedes because we weren't hysterical enough" (Keneally 2013: 161) echoes the debates after the sinking of the Marquette and the more general difficulties with reconciling women's active courage with gender stereotypes. Empowered by her performance during the tragic accident, at the Number 3 Australian General Hospital on the island of Lemnos, Naomi protests to the colonel in charge against the practice of transporting soldiers and military equipment on a hospital ship, which made the

qualities of service, duty and care" (Christie 2014: 233). Christie associates the resurgence of interest in the Marquette story in the last twenty years with "the renewed interest in commemorating Anzac Day and its associated symbols and stories as 'markers of nationhood" (Christie 2014: 238). The debate around the nurses' evacuation has increasingly focused on why a medical unit would travel with troops on an ammunition ship; the nurses are thus portrayed as tragic victims of irresponsible imperial decisions rather than German brutality (Christie 2014: 233-239). 
Archimedes the target of the U-boat and led to the death of six women. She also demands that the Australian sisters be granted a military rank. Her challenge to the model of woman "as mirror, as 'other', as marginal and supportive" (Butler 2003: 52) causes her, eventually, to be severely punished.

According to historical sources, the conditions in which the nurses lived and worked in 1915 on Lemnos, sixty kilometers away from Gallipoli, were spartan. They lacked basic resources and tore their own clothes to dress the men's wounds. Within twelve months they treated 100,000 patients (Butler 2003: 49; The Nurses' Experience 2015: 9; AWM). In The Daughters of Mars, the nurses are exposed to hunger, cold, disease, lack of sanitation, and extreme fatigue. Moreover, the conservative military commander believes women are "an imposition" in the war zone (Keneally 2013: 158). As a result, the female protagonists are not allowed to administer medical procedures; they only scrub the wards, clean excrement and lug buckets of used dressing and amputated limbs to the furnace, while the semi-trained orderlies are in power. According to Hallett (2014: 27), "Although belonging to highly-trained and dedicated cadres of workers, military nurses were, at times, treated as if their presence on the wards of military hospitals were a mere exercise in propaganda". In Keneally's novel the sisters are also humiliated by the orderlies and one of them is a victim of sexual assault. As Butler explains, at the outbreak of the First World War men were not accustomed to women in war zones and their position of authority was most unsettling to the male staff; as a result they did not pay respect to orders issued by women. Although the Australian nurses had a at least three years training and were experienced professionals, the medical officers on Lemnos were completely satisfied with the work of the orderlies, who had received only three months of training (Butler 2003: 51-52; Rees 2015: 106107). ${ }^{11}$ In The Daughters of Mars, the majority of sisters are so terrorized that they accept this balance of power, as reported in the real nurses' memoirs (Butler 2003: 53), with the exception of Naomi, who becomes increasingly angry. When Nettice, the Durance sisters' friend, is sent to a mental ward for flirting with a blind soldier, Naomi breaks the orders and visits her colleague, as a result of which she is suspended and sent back to Australia in disgrace.

Gallipoli, the sinking of the Archimedes, and her experience on Lemnos enlighten Naomi as to her personality and transformation. Back in Australia, she

11 Lieutenant General R. H. J. 'Bertie' Fetherston, the Director-General of Australian Army Medical Services (represented in The Daughters of Mars by Colonel Leatherhead), on a tour of inspection on Lemnos, was outraged by the conditions in which the nurses worked and recommended "the wearing of badges of rank by Australian nurses, in a manner similar to the nearby Canadian nurses. This measure, encoding them as army officers rather than civilian women, was adopted in 1916", after the fictional Durance sisters left Lemnos (Butler 2003: 52; also see Rees 2015: 108). 
is restless at the Randwick military hospital, where "Patients were admitted not in a calamitous flood but one at a time" (Keneally 2013: 242). To fit back into the quiet of Australian life after the rush and excitement of war proves most difficult: she suffocates in spite of the good intentions of her father's new wife. Talking to Lieutenant Kiernan, an orderly whom she will finally become engaged to, she comprehends that she is addicted to war: the desire to see how much men can endure and inflict "is like a disease (...) to want to tend deaths instead of births" (Keneally 2013: 230). She realizes that "The war had made a misfit of her" (Keneally 2013: 242). This is why she is exhilarated when she is accepted as a military nurse again. Consequently, the female protagonist redefines her identity as a woman and a nursing sister, beyond the duty above self, expected of both of them (Stuart 2008: 13). The animosity and adversity she has experienced result in an "an expanded sense of what being female could encompass" (Butler 2003: 57). The unfair degradation she suffered on Lemnos also makes Naomi, like many real-life Australian nurses, "more assertive and less likely to accept poor treatment" (Butler 2003: 54). As a result, disappointed in the military, she chooses to work at a private Australian hospital at Château Baincthun, Boulogne, where she enjoys much more independence. Reunited with Sally in France, Naomi comes to the peculiar conclusion that they are "happier now - at this second and here - than in [their] past lifetime there" (Keneally 2013: 306). She envisages a future for them together, for no one else might be able to understand the horrors they have experienced. They are both possessed by a "desire to find a home with the gods of sacrifice" (Keneally 2013: 274) and become the adopted daughters of Mars.

While Naomi's story becomes increasingly a narrative of rebellion against the army and its rigid principles, ${ }^{12}$ the horrors of the Western Front, where Australian nurses were relocated in $1916,{ }^{13}$ are depicted in The Daughters of Mars from Sally's point of view. Initially, when she works at the Number 3 Australian General Hospital at Rouen, she believes that "this French affair was a better-ordered war altogether than the hit-and-miss affair at Gallipoli" (Keneally 2013: 267). Nevertheless, at the gas wards, she is confronted with "less contained savagery" and "enter[s] a new continent of human bile"

12 An important theme explored in the Naomi-centered plot is the problem of conscientious objection and the persecution of her Quaker fiancé. During her work at Boulogne Naomi also becomes the object of lesbian love, an important departure from the classical war tradition centered on heterosexual relationships (see Rhoden 2014: 276). The love relationships with Australian soldiers that the Durance sisters and several of their friends manage to build in the extreme circumstances of war add to the human dimension of The Daughters of Mars.

13 One New Zealand stationary hospital, three Australian general hospitals and three Australian casualty clearing stations were opened on the Western Front. Many AANS nurses also worked in British and Canadian medical units (Rees 2015: 158). 
(Keneally 2013: 268-269). Moreover, she volunteers for casualty clearing stations, closer and closer to the front, where the stress exceeds the tension experienced at Gallipoli. According to Harris (2014: 114), "Hailed as 'a mecca to which all good nurses aspire, CCS work required superior theatre skills as well as the ability to 'triage,' to keep patients alive, and to ease the suffering of those who were dying". Although excluded from battle, Sally confronts shelling, air raids, hasty evacuations, and the general hardships of front life. While the tension between a sense of being simultaneously at the periphery and at the center is represented as problematic in many First World War nurses' testimonies (Das 2005: 188), Sally derives from her experience a profound insight into the nature of war. Talking to her lover Charlie, she confesses:

It's like a new world where there aren't any words. As for me, I've only worked
around the edges .... Well, it's true you seem to be a different person when these
things happen. Not your daily self. You'll find that. I wasn't my ordinary self
when the ship sank. I was another creature. And that creature finds it hard to
explain things.

(Keneally 2013: 259)

In this short quotation, Keneally encapsulates the classic symptoms of a soldier's adaptation to the conditions of war. ${ }^{14}$ Moreover, the ineffability of trauma, which evades cognitive ordering and verbalization, is one of the basic tenets of trauma theory. Although the nurse is situated "around the edges", the above quotation suggests a continuity between the experience of combatants and nursing sisters.

At the end of the novel, Kenneally portrays the two sisters' serene reunion before the tragic denouement. During their brief meeting in Paris, Naomi reveals to Sally that their mother died of natural causes and she did not poison her. Sally's lover Charlie compares her desire to kill her mother to the merciful impulse soldiers feel towards their comrades caught in the wire. The brutality of the front situates the concept of "murder" itself in a different perspective. The Durance sisters look forward to rebuilding their lives in Australia. Nevertheless, after a delightful time in Paris, both sisters succumb to influenza in the summer of 1918. The Daughters of Mars offers two alternative endings, suggesting that one sister died, while "the other one had married a man from Sydney or Melbourne, a returned soldier" (Keneally 2013: 506). A postmodern game with the reader, the alternative endings render powerfully, however, the arbitrariness of death in war.

The Daughters of Mars seems to be consistent with the general tone of Australian Great War fiction, in which "the war experience is not just horrific,

14 In extreme circumstances the sense of self is radically altered and a new self is created to deal with the atrocities of war (see, e.g., Caruth 1995b: 137). 
but also worthwhile, adventurous, and constructive" (Rhoden 2014: 277). ${ }^{15}$ Keneally's protagonists reject the fetishized image of nurses as "angels of mercy and compassion" (Das 2005: 202); they do not enlist because of a masochistic impulse of self-sacrifice, but, like many real men in the dominions during the First World War, are driven by the prospect of adventure and the need to prove themselves in a righteous cause. As in several other Australian war texts, in The Daughters of Mars war is "a task to be done, involving all the danger and discomfort of difficult tasks" which provide individual actions with meaning (Rhoden 2014: 276). The emotional ties between women that Keneally depicts in his novel also complement a literary tradition focused mostly on men: the bond between the sisters, which develops in the extreme conditions of war, can be interpreted as an alternative to the myth of mateship inherent to the Australian tradition. Whereas the theme of "brotherhood of the trenches" has been fictionalized in several First World War novels, such as, in the Australian case, 1915 (1979) by Roger McDonald, sisterhood remains a relatively neglected aspect of World War One studies/literature. The Daughters of Mars therefore rewrites from a woman's perspective the conventions of First World War writing "from the subaltern's progression from innocence to experience in the war, through the representation of the war's horrors and the bravery of individual soldiers at the front, to the representation of how difficult it is for returning soldiers to return to their lives at home" (Gordon 2014: 153).

By depicting an "unclaimed experience", The Daughters of Mars cements the myth of the First World War nurse as a war heroine. ${ }^{16}$ The novel challenges the male-centered myth of the Anzac by including women in the story of the war and by locating trauma in their exhausted, emaciated bodies. Yet, synchronously, it reaffirms the digger values associated with the Anzac tradition, for the "other Anzacs" in Keneally's novel are women of action: they share their strength, bravery, camaraderie, loyalty, and love of independence with their male counterparts. The courage, stoicism, and selflessness with which they perform their stupendous feats of endurance, as well as the enormity of the tasks with which they are confronted, function in the novel as ennobling factors. Keneally's female protagonists are "misfits" of war, proud to be part of the global conflict, in a community of women increasingly conscious of their achievements. Importantly, by contrasting the reaction of the two sisters, the novel shows that there are various ways of coping with war trauma:

15 It is important to emphasize that the historical sources used by Keneally seem to sustain this perspective, particularly Peter Rees's historical works, many incidents from which are directly fictionalized in The Daughters of Mars.

16 In a similar vein, a bronze memorial in recognition of Australian nurses' achievement on Lemnos was unveiled in Melbourne on 8 August 2015, a hundred years after the nurses' arrival on the island. 
"breakdown and resilience are not experienced as oppositional states, but exist on a continuum, and a part of a range of responses to wartime medical practice" (Acton \& Potter 2015: 50-51). Ultimately, in spite of trauma and degradation, war proves a positive experience for the Durance sisters, which might be seen as controversial in a pacifist twenty-first century. ${ }^{17}$

The Daughters of Mars does not involve a radical critique of imperial war propaganda. The female protagonists do not experience any doubts about their involvement in the imperial and nationalist war machine. Keneally's agenda is to reclaim a neglected facet of war, to include the heroic Australian nurses in the Australian collective memory as an integral part of the Anzac war effort, and not to examine Australia's imperial loyalties. In spite of the digger's legendary defiance, towards the British in particular (see Seal 2004: 3), the Anzac myth remains imbricated in its imperial legacies. Yet, taking into consideration the construction of motherhood in the imperial propaganda, the theme of matricide in The Daughters of Mars seems most intriguing. Imperial soldiers were represented as children of the Empire, willing to accept the ultimate sacrifice for Mother Britain. The figure of the noble, devoted mother inspiring soldiers to fight for Britain and the Empire was also part of the propaganda (Cooper 1993: 410, 413; Evans 2007: 79-105). In Keneally's novel, the Durance sisters see themselves as killers of their mother. The severance with the mother's body as if predestines them to enter the world of men - the world of war. Importantly, for young women in the Anglo-Saxon world at the turn of the twentieth century, dis-identification with the maternal body signaled "freedom from a reproductive destiny and a construction of femininity seen as constraining and suffocating" (Bordo 1995: 209). To serve as a nurse during the First World War represented therefore an important alternative to traditional lifestyles.

In a more psychoanalytic perspective, however, the mother's diseased body functions in The Daughters of Mars as the Kristevan abject site of life and death, an intriguing revision of the imperial motherhood image discussed above. The trope of matricide erases maternal contribution to "selfhood" and thus initiates a social order based on the Law of the Father (Green 2012: 3), whose "civilizing" mission ultimately involves trauma and death. Taking care of the debris of male flesh, the Durance sisters "act out the pollution of a distorted ideology that implicates motherhood with war, the female body with dirt and death" (Marcus 1989: 126). ${ }^{18}$ This perspective, however, is not really addressed

17 Action, skills, and devotion are important features of the Anzac soldier in Australian literature, which contrasts with the disenchanted victim infantryman of canonical British First World War novels. As a result, the pacifist impulse seems less strong in Australian than in British fiction (Rhoden 2014: 276).

18 An issue illuminated in recent British and Canadian novels of the First World War, such as, for instance, Louisa Young's My Dear, I Wanted to Tell You (2011) or Jane 
in the text, which is slightly disappointing in such an important historical novel centered on women. The Daughters of Mars saves Australian nurses' trauma from oblivion, yet the novel does not explore female grief and mourning in the confrontation with massive death. The transformation experienced by the female protagonists is of a positive and heroic nature - war has the potential to trigger what is best in a (wo)man's character and brings people together, instead of drawing them apart. If Keneally's text is a historical novel of an impressive scope, which reclaims the Australian nurses' war experience and thus plays a significant role in revising collective memory, the acceptance of the imperialist ideologies by the "daughters of Mars" leaves unanswered important questions about Australian women's acquiescence to the first global conflict.

\section{REFERENCES}

\section{PRIMARY SOURCES}

Borden, Mary. 2008 [1929]. The forbidden zone. London: Hesperus Press Limited.

Brittain, Vera. 2014 [1933]. Testament of youth. London: Phoenix.

Hemingway, Ernest. 1929. A farewell to arms. New York, NY: Scribner.

Keneally, Thomas. 1975. Gossip from the forest. London/Sydney: Collins.

Keneally, Thomas. 2013. The daughters of Mars. New York, London, Toronto, Sydney, New Delhi: Atria Books.

McDonald, Roger. 1979. 1915. St Lucia: University of Queensland Press.

Urquhart, Jane. 1997. The underpainter. London: Penguin Books.

Young, Louisa. 2011. My dear, I wanted to tell you. London: The Borough Press.

\section{SECONDARY SOURCES}

Acton, Carol. 2015. "Kitchener's tourists": Voices from Great War hospital ships. In Kellen Kurschinski, Steve Marti, Alicia Robinet, Matt Symes \& Jonathan F. Vance (eds.), The Great War: From memory to history, 215-234. Waterloo: Wilfrid Laurier University Press.

Acton, Carol \& Jane Potter. 2015. Working in a world of hurt: Trauma and resilience in the narratives of medical personnel in warzones. Manchester: Manchester University Press.

AWM = Australian War Memorial, https://www.awm.gov.au/exhibitions/nurses/ww1 (accessed 3 May 2017).

Bird, Delys. 2000. New narrations. In Elizabeth Webby (ed.), The Cambridge companion to Australian literature, 183-208. Cambridge: Cambridge University Press. DOI: 10.1017/CCOL0521651220.008

Urquhart's The Underpainter (1997). In this respect, The Daughters of Mars, much less informed by contemporary trauma studies, seems a more conservative text. Stoic acceptance of war realities is, however, characteristic of the Australian war canon (Rhoden 2014: 276). 
Bongiorno Frank. 2014. Anzac and the politics of inclusion. In Ben Wellings \& Shanti Sumartojo (eds.), Nation, memory and Great War commemoration: Mobilizing the past in Europe, Australia and New Zealand, 81-97. Bern: Peter Lang.

Bordo, Susan R. 1995. Unbearable weight: Feminism, Western culture, and the body. Berkeley, Los Angeles, London: University of California Press.

Bourke, Joanna. 1996. Dismembering the male: Men's bodies, Britain and the Great War. London: Reaktion Books.

Butler, Arthur G. (ed.) 1930-1943. The Australian army medical services in the war of 19141918. 3 vols. Melbourne, Australian War Memorial.

Butler, Janet. 2003. Nursing Gallipoli: Identity and the challenge of experience. Journal of Australian Studies 27(78). 47-57. DOI: 10.1080/14443050309387870

Caruth, Cathy. 1995a. Introduction to Part I: Trauma and experience. In Cathy Caruth (ed.), Trauma: Explorations in memory, 3-12. Baltimore \& London: The Johns Hopkins University Press.

Caruth, Cathy. 1995b. An interview with Robert Jay Lifton. In Cathy Caruth (ed.), Trauma: Explorations in memory, 128-147. Baltimore \& London: The Johns Hopkins University Press.

Christie, Sarah. 2014. The sinking of the Marquette: Gender, nationalism and New Zealand's Great War remembrance. In Ben Wellings \& Shanti Sumartojo (eds.), Nation, memory and Great War commemoration: Mobilizing the past in Europe, Australia and New Zealand, 225-241. Bern: Peter Lang.

Cooper, Annabel. 1993. Textual territories: Gendered cultural politics and Australian representations of the war of 1914-1918. Australian Historical Studies 25(100). 403421. DOI: $10.1080 / 10314619308595923$

Das, Santanu. 2005. Touch and intimacy in First World War literature. Cambridge: Cambridge University Press. DOI: 10.1017/CBO9781107295575

Evans, Suzanne. 2007. Mothers of heroes, mothers of martyrs: World War I and the politics of grief. Montreal: McGill-Queen's University Press.

Gadzina, Tomasz. 2015. The Anzac legend and Australian national identity one hundred years after the Great War. In Anna Branach-Kallas \& Nelly Strehlau (eds.), Re-imagining the First World War: New perspectives in Anglophone literature and culture, 234246. Newcastle upon Tyne: Cambridge Scholars Publishing.

Gordon, Neta. 2014. Catching the torch: Contemporary Canadian literary responses to World War I. Waterloo: Wilfrid Laurier University Press.

Grayzel, Susan R. 1999. Women's identities at war: Gender, motherhood, and politics in Britain and France during the First World War. Chapel Hill \& London: The University of North Carolina Press.

Green, Laura. 2012. Myths, matricide and maternal subjectivity in Irigaray. Studies in the Maternal 4(1). http://www.mamsie.bbk.ac.uk/ (accessed 15 January 2013).

Hallett, Christine E. 2014. Veiled warriors: Allied nurses of the First World War. Oxford: Oxford University Press.

Harris, Kirsty. 2014. New horizons: Australian nurses at work in World War I. Endeavour 38(2). 111-121. DOI: 10.1016/j.endeavour2014.05.004

Herman Lewis, Judith. 1992. Trauma and recovery. The aftermath of violence-From domestic abuse to political terror. New York: Basic Books.

Higonnet, Margaret Randolph, Jane Jenson, Sonya Michel \& Margaret Collins Weitz. 1987. Introduction. In Margaret Randolph Higonnet, Jane Jenson, Sonya Michel \& Margaret Collins Weitz (eds.), Behind the lines: Gender and the two world wars, 117. New Haven \& London: Yale University Press.

Keshen, Jeff. 2003. The Great War soldier as nation builder in Canada and Australia. In Briton C. Busch (ed.), Canada and the Great War: Western front association papers, 3-26. Montreal \& Kingston, London, Ithaca: McGill-Queen's University Press. 
Kristeva, Julia. 1982. Powers of horror: An essay on abjection. (Translated by Leo S. Roudiez.) New York, NY: Columbia University Press.

Lake, Marylin, Henry Reynolds, Mark McKenna \& Joy Damousi. 2010. What's wrong with Anzac? The militarisation of Australian history. Sydney: University of New South Wales Press.

Marcus, Jane. 1989. Corpus/corps/corpse: Writing the body in/at war. In Helen M. Cooper, Adrienne Auslander Munich \& Susan Merrill Squier (eds.), Arms and the woman: War, gender, and literary representation, 124-167. Chapel Hill \& London: The University of North Carolina Press.

Ouditt, Sharon. 1994. Fighting forces, writing women: Identity and ideology in the First World War. London \& New York: Routledge.

Pierce, Peter. 2015. The making of Thomas Keneally. Australian Literary Studies 30(1). 40-51. DOI: $10.20314 /$ als.c4c4bbd9b1

Rees, Peter. 2009. The other Anzacs: The extraordinary story of our World War I nurses. Crows Nest: Easyread Large.

Rees, Peter. 2015. Anzac girls. London: Allen \& Unwin

Reynaud, Daniel. 2014. National versions of the Great War: Modern Australian Anzac cinema. In Martin Löschnigg \& Marzena Sokołowska-Paryż (eds.), The Great War in postmemory literature and film, 289-303. Berlin/Boston: De Gruyter.

Rhoden, Clare. 2014. Even more Australian: Australian Great War novels in the twenty-first century. In Martin Löschnigg \& Marzena Sokołowska-Paryż (eds.), The Great War in post-memory literature and film, 273-288. Berlin/Boston: De Gruyter.

Roper, Michael. 2009. The secret battle: Emotional survival in the Great War. Manchester \& New York: Manchester University Press.

Seal, Graham. 2004. Inventing Anzac: The digger and national mythology. St Lucia: University of Queensland Press.

Simon, Scott. 2013. Sisterly conflict against a Great War backdrop in Daughters of Mars. Weekend Edition Saturday (NPR) 24 August. https://www.npr.org/templates/transcript/transcript.php?storyId=214846038 (accessed 4 May 2017).

Spittel, Christina. 2014. Nostalgia for the nation? The First World War in Australian novels of the 1970s and 1980s. In Martin Löschnigg \& Marzena Sokołowska-Paryż (eds.), The Great War in post-memory literature and film, 255-272. Berlin/Boston: De Gruyter.

Stuart, Meryn. 2008. Social sisters: A feminist analysis of the discourses of Canadian military nurse Helen Fowlds, 1915-18. In Jayne Elliott, Meryn Stuart \& Cynthia Toman (eds.), Place and practice in Canadian nursing history, 25-39. Vancouver: University of British Columbia Press.

The Nurses' Experience $=$ The Department of Veterans' Affairs. 2015. The nurses' experience of Gallipoli from their letters. Day Surgery Australia 14(1). 7-9.

Trevisan, Carine. 2001. Les fables du deuil. La Grande Guerre: Mort et écriture. Paris: Presses Universitaires de France. 